Article

\title{
Food Losses and Wastage along the Wheat Value Chain in Egypt and Their Implications on Food and Energy Security, Natural Resources, and the Environment
}

\author{
Yigezu A. Yigezu ${ }^{1, *(D)}$, Moustafa A. Moustafa ${ }^{2}$, Mohamed M. Mohiy ${ }^{2} \mathbb{D}$, Shaimaa E. Ibrahim ${ }^{2}$, Wael M. Ghanem ${ }^{2}$, \\ Abdoul-Aziz Niane ${ }^{3}$, Enas Abbas ${ }^{2} \mathbb{D}$, Sami R. S. Sabry ${ }^{2}$ and Habib Halila ${ }^{4}$ \\ 1 International Center for Agricultural Research in the Dry Areas (ICARDA), Cairo 11711, Egypt \\ 2 Agricultural Research Center (ARC) of Egypt, Cairo 12619, Egypt; m.azab.nwrp@hotmail.com (M.A.M.); \\ mohamed.mohiy@yahoo.com (M.M.M.); shaimaaeldesoky729@yahoo.com (S.E.I.); \\ drwael2020@yahoo.com (W.M.G.); enas_abbas_saleh@yahoo.com (E.A.); samisabry@yahoo.com (S.R.S.S.) \\ 3 International Center for Agricultural Research in the Dry Areas (ICARDA), Dubai 13979, United Arab Emirates; \\ A.Niane@cgiar.org \\ 4 International Center for Agricultural Research in the Dry Areas (ICARDA), Tunis 1302, Tunisia; \\ H.Halila@cgiar.org \\ * Correspondence: Y.Yigezu@cgiar.org
}

check for updates

Citation: Yigezu, Y.A.; Moustafa, M.A.; Mohiy, M.M.; Ibrahim, S.E.; Ghanem, W.M.; Niane, A.-A.; Abbas, E.; Sabry, S.R.S.; Halila, H. Food Losses and Wastage along the Wheat Value Chain in Egypt and Their Implications on Food and Energy Security, Natural Resources, and the Environment. Sustainability 2021, 13, 10011. https://doi.org/10.3390/ su131810011

Academic Editors: Felicitas Schneider, Stefan Lange and Thomas Schmidt

Received: 11 July 2021

Accepted: 24 August 2021

Published: 7 September 2021

Publisher's Note: MDPI stays neutral with regard to jurisdictional claims in published maps and institutional affiliations.

Copyright: (c) 2021 by the authors. Licensee MDPI, Basel, Switzerland. This article is an open access article distributed under the terms and conditions of the Creative Commons Attribution (CC BY) license (https:// creativecommons.org/licenses/by/ $4.0 /)$.

\begin{abstract}
Pushing yield frontiers of cereals and legumes is becoming increasingly difficult, especially in drylands. This paper argues and provides empirical evidence that food loss and wastage constitute a sizeable proportion of the total wheat supply in Egypt. By following the life cycle of food and using standard measurement protocols, we estimated the levels of food loss and wastage along the wheat value chain in Egypt and their socioeconomic, biophysical, and environmental implications. About 4.4 million tons (20.62\% of total wheat supply from domestic production and imports in $2017 / 2018$ ) is estimated to be lost or wasted in Egypt which is also associated with the wastage of about 4.79 billion $\mathrm{m}^{3}$ of water, and 74.72 million GJ of energy. This implies that if Egypt manages to eliminate, or considerably reduce, wheat-related losses and wastage, it will save enough food to feed 21 million more people from domestic production and hence reduce wheat imports by $37 \%$, save 1.1 billion USD of much-needed foreign exchange, and reduce emissions of at least 260.84 million $\mathrm{kg}$ carbon dioxide-equivalent and 8.5 million $\mathrm{kg}$ of methane. Therefore, investment in reducing food loss and wastage can be an effective strategy to complement ongoing efforts to enhance food security through productivity enhancement in Egypt.
\end{abstract}

Keywords: wheat; value chain; food loss; food waste; food and energy security; natural resources and environment

\section{Introduction \\ 1.1. Background}

Food insecurity is one of the major challenges facing humanity today. Cereals are the main food staples globally, out of which, wheat is the most important crop characterized by a sizeable gap between production and consumption in most countries. This is more so in the Middle East and North African (MENA) region where domestic production and imports account for an equal share of food supplies, making MENA the most import-dependent region in the world [1,2]. The fast population growth and projected climate change will make the entire region warmer and drier with lesser precipitation in the future [3]. As a result, the region's dependence on imports is expected to increase [4]. Being the most populous country and non-oil economy in the region, this trend is expected to affect Egypt the most. Egypt is the world's largest wheat importing country, which imported about 12.80 million tons of wheat in 2019/2020 (about 53\% of total supply), projected to increase to 12.85 million tons in $2020 / 2021$ [5]. 
Increasing wheat supply from domestic sources can be achieved through one or more of the following options: (1) increasing wheat area, (2) raising productivity per unit area, and (3) reducing food loss and wastage. The first option is neither practical nor sustainable as most lands suitable for agriculture are already used in many parts of the world. Moreover, any effort towards area expansion in MENA has substantial environmental and natural resource implications. The second option, increasing productivity through sustainable intensification, is feasible and desirable. Indeed, it has been the main strategy employed by governmental and non-governmental organizations to increase food supply. While this strategy has achieved its objective of increasing the global food supply, food insecurity remains a major challenge in many parts of the world, including MENA. This shows that efforts to increase food supply through crop improvement alone are not and will not be sufficient to meet the food demand of a growing world population, which is projected to reach 9.7 billion by 2050 [6-8].

The third option is incredibly neglected but strategically crucial because one-third of the global food production, which is equivalent to 1.3 billion tons, is lost or wasted every year [9]. Such a high and growing level of loss and wastage is now casting doubt if the world can realistically meet the food needs of its projected large population [10]. In the face of this dilemma, making full use of every bit of produced food should be given the utmost priority. Therefore, dealing with the growing challenge of food insecurity requires the development of effective strategies that enhance the momentum of past productivity gains and radically reduce food loss and waste. Another study [11] suggested that reducing the post-harvest losses could be a sustainable solution to increase food availability, reduce pressure on natural resources, eliminate hunger, and improve farmers' livelihoods. In the face of fast population growth, the concern about the consequences of climate change and the ever-increasing degradation and depletion of natural resources, including water and land (the two main factors of agricultural production) is growing. We argue that reducing food loss and waste should be at the top of the food security agenda, especially in regions such as MENA where rapid land degradation and CC are observed. Food loss and waste have significant implications on ensuring food security, natural resource management, and mitigating CC, not to mention ethical considerations.

Assessing food loss and wastage is quite a complex and difficult task. This study was conducted in Egypt and was based, wherever possible, on data collected from physical measurements. When physical measurements were neither practical nor culturally acceptable, surveys were used, and company records of food processors and storage facilities were consulted. By employing the life cycle of food approach, suggested by [12], this study tried to provide estimates of food loss and wastage at each node of the wheat value chain from the field to fork. It also attempts to estimate the implications on food security, energy, natural resources, and the environment.

\subsection{Wheat in Egypt}

Wheat is the most important cereal crop in Egypt because wheat bread, macaroni, and other baked goods are important in Egyptian diets. Wheat-based products account for about $30 \%$ of caloric intakes for Egyptians, and wheat straw is used to feed livestock. In Egypt, wheat is grown on about 1.4 million ha of land. In 2020, the average yield was about 6.42 tons/ha-the highest in Africa. However, there is still a sizeable gap between consumption and production, which, in the last 20 years, averaged between $41 \%$ and $68 \%$ [13]. This gap leaves the country heavily reliant on imports that put pressure on its foreign exchange reserve. Egypt has adopted the strategy of decreasing the gap between production and consumption through three different avenues: expanding the wheat area into the newly reclaimed lands, increasing grain productivity (vertical expansion), and decreasing wheat losses along the wheat value chain from field to fork. Egypt achieved good progress in developing new wheat cultivars with high yield potential and developing good agricultural practices to maximize grain yield per unit area. Expanding wheat areas is limited due to the scarcity of water resources. In addition to losses in the imported 
wheat, the harvest and post-harvest losses along the wheat value chain are estimated at more than 1 million tons of grain. These losses represent about $13-15 \%$ of the local wheat production [14], suggesting that reducing harvest and post-harvest losses is more important than the different strategies and efforts deployed to achieve food self-sufficiency. Table 1 presents the trends in wheat area, productivity, and total production from 1981 through 2020. Wheat production has increased from 1.94 million tons in 1981 to 8.49 million tons in 2020, almost equally attributed to productivity gains and area expansion. Although the improvement in total production is about four times during the last four decades, there is limited opportunity for further increases due to growing scarcity in water resources which constrains both area expansion and productivity gains. Therefore, decreasing wheat loss and wastage along the entire value chain (known to be high in Egypt) can save substantial amounts of food and save the country significant foreign exchange from imports. As shown in the theoretical framework for this study in Figure 1, wheat loss and food wastage can occur during storage, processing, marketing, and transportation. Losses happen on the field because most farmers don't follow the optimal management practices. Losses also occur between physiological maturity and harvest due to lodging, shattering, rodent, and bird attacks. Significant losses occur during harvesting, bundling (for manual and reaper harvesting), transporting, and threshing. Substantial losses are also observed in governmental storages, especially in open air storages locally called "Shona" that do not provide protection from birds, rodents, weather changes, and insect infestation. These problems are believed to cause not only wheat loss but also health problems. The qualitative changes caused during production, transportation, and storage also have implications on the magnitude of food wastage during consumption. In Egypt, government purchases represent the main marketing outlet for local production. Therefore, the highest level of loss is expected to occur in this part of the value chain particularly during storage in Shona where losses are estimated between 10-20\% [15].

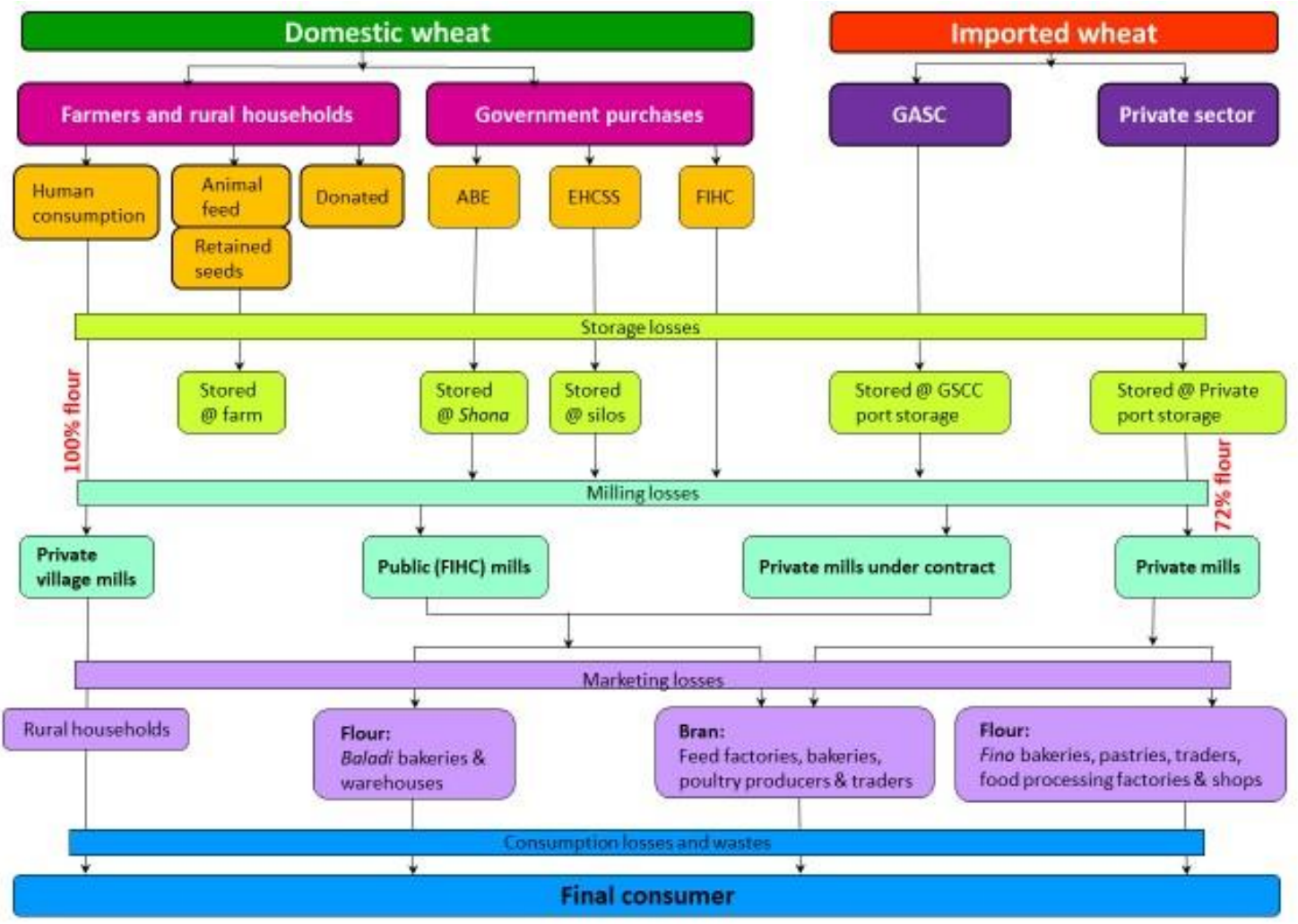

Figure 1. Schematic representation of the wheat value chain in Egypt and the theoretical framework of the study. GCSS: General company for silos and storage; GASC: General Authority for supply commodities; FIHC: Food Industries Holding company; ABE: Agricultural Bank of Egypt. EHCC: Egyptian Holding company for silos and storage. 
Table 1. National total wheat area, average yield, and total production from 1981 to 2020.

\begin{tabular}{cccc}
\hline Year & $\begin{array}{c}\text { Wheat Area } \\
\text { (Million Hectare) }\end{array}$ & $\begin{array}{c}\text { Average Yield } \\
\text { Ton/Ha }\end{array}$ & $\begin{array}{c}\text { Total Production } \\
\text { Million Ton }\end{array}$ \\
\hline 1981 & 0.588 & 3.31 & 1.94 \\
1986 & 0.570 & 3.81 & 1.93 \\
1991 & 0.931 & 4.83 & 4.48 \\
1996 & 1.017 & 5.64 & 5.74 \\
2001 & 0.984 & 6.35 & 6.26 \\
2006 & 1.257 & 6.43 & 8.27 \\
2011 & 1.277 & 6.53 & 8.37 \\
2016 & 1.417 & 6.66 & 9.40 \\
2020 & 1.331 & 6.37 & 8.49 \\
\hline
\end{tabular}

Source: Economic Affairs Sector, Ministry of Agric. and Land Reclamation, Egypt.

\section{Review of the Literature on Food Loss and Wastage}

Most past studies lack accurate quantitative data on scale, origins, causes, and nature of food loss and wastage. A global study [9] commissioned by the Food and Agriculture Organization of the United Nations was the first systematic effort to quantify food loss and wastage (FL\&W) at global and regional levels. It estimated that around one third of all food produced in the world is lost and/or wasted. The study indicated that up to $68 \%$ FL\&W North Africa and West and Central Asia occur during production, handling, processing, and distribution. Waste at the consumption stage is estimated to be $32 \%$ and occurs mostly in urban centres. Significant waste takes place during religious occasions especially the fasting month of Ramadan, and social events such as wedding ceremonies and family gatherings.

\subsection{Loss and Wastage in MENA}

Food waste remains a relatively unexplored topic, especially in West Asia and North Africa region [16]. Except for [17] and [18], the few available studies in MENA either are limited to only one or few nodes along the value chain, and some of them do not follow the Food Loss and Waste (FLW) measurement Protocol developed by the international initiative led by the World Resource Institute [19]. In Jordan, [17] found that $34 \%$ of the total wheat supply (from both local production and imports) is lost or wasted, costing the country about 105 million USD per year. The study found that at $12.95 \%$ of total wheat supply, food waste during consumption ranked first, followed by milling loss. A recent study [18] also found that $42 \%$ of the total food supply in Morocco is lost or wasted, where at $17 \%$ and $11 \%$ of total wheat supply, farm management-related losses and wastage during consumption rank the top-two sources of loss.

Though it does not document the procedures used in the measurement or estimation of food loss, [20] estimates losses for different food groups (cereals, legumes, vegetables, etc.) from production to consumption in the Arab world. The study estimated that $30 \%$ of total cereal production in the Arab world is lost between production and consumption.

In Iran, [21] measured wheat losses during pre-harvest, and harvest stages using two wheat varieties and two types of John Deere combine harvesters. They found that higher amounts of losses $(6.83 \%)$ were found in the fields planted with the Omid variety and harvested using a JD 955 combine, while the lowest (3.97\%) losses were observed in fields planted with the Alvand wheat variety, which were harvested using a JD 1165 harvester. Pre-harvest losses in all fields constituted an average of $9.8 \%$ of total losses. In a study carried in three districts of Turkey, [22] compared harvest losses between systems that use combine harvesters with conventional header and systems that use stripper header under three different speeds and moisture contents. The study found that grain losses in harvesting with stripper header decreased with increased forward speed and moisture content. In contrast, grain losses for stripper header were approximately half of the conventional one. 
Another study carried in Turkey [23] analyzed the effects of different storage building types on wheat quality and found that the temperature and moisture content affected quality parameters, including hectoliters, gluten index, sedimentation, and sunn pest. Lack of running aeration system increased temperature leading to low wheat quality.

A study carried in selected Mediterranean countries explored the extent of wastage in bread and bakery products [24]. The study used secondary data from different sources as well as the results of an online exploratory survey on household food waste carried out in the period January-May 2015 which interviewed 1122 adult consumers in Algeria, Egypt, Lebanon, Morocco, and Tunisia. The study found that wastage of bakery products in some households can go up to $20 \%$ with subsidized bread used even as animal or fish feedstuff. Bread wastage was higher during the fasting month of Ramadan.

Some studies were also carried in Egypt, which is the focus of this study. One study [25] compared different methods of harvesting and threshing in Egypt and found that losses during manual harvest and harvest using reapers were $3.16 \%$ and $2.7 \%$, respectively, while losses during harvesting and threshing by combine were $2.92 \%$. Another study [26] investigated the changes in wheat grain quality during storage for 12 months in two years using different types of containers. They found that moisture content increased in cotton bags and earthen pots, resulting in higher test weight and flour yield. Tin containers performed better in retaining low-fat acidity values. The falling number was increased in all containers during storage but remained within limits required for baking purposes.

\subsection{Food Loss and Wastage in Other Parts of the World}

In a study carried in the United States, [27] it was reported that combine adjustment can affect wheat quality in two ways, i.e., grain damage and cleanliness. Broken kernels generate dust, harbor insects, and increase mold growth. They estimated grain damage between $0.5-2.0 \%$, and it can be much higher. They also reported that grain losses from rotary combines do not increase as rapidly at higher feed rates as they do on conventional combines. If the feed rate is increased by $50 \%$, the rotary combine losses may increase to $8 \%$, while it can be as high as $16 \%$ with the conventional combines.

Several studies were carried in Pakistan to measure postharvest losses. Two studies recorded losses of $3.7 \%$ and $2.1 \%$, respectively, during the manual harvest of wheat $[28,29]$. Another study [30] recorded between 5.8 to $11.8 \%$ losses during harvest using reapers. The average grain losses during conventional harvesting, bundling, transporting, threshing, winnowing, and cleaning were $3.67,3.98,0.24,1.18,2.46$, and $4.53 \%$, respectively [31]. Yet another study carried in Pakistan [32] found grain losses of 1.19, 2.63, and 2.76\% using three front-mounted reapers manufactured by three different factories.

The main factors that affect grain during storage are moisture, temperature, and humidity of the storage environment. Other factors responsible for deterioration are poor containers, damage by rodents, insect pests, and microorganisms. All mentioned factors and others bring chemical changes and weight loss as well as changes in quality [33]. A study which provided a review of the literature on storage loss and reported that insect pests cause average losses of between $30-40 \%$ and even much higher [11]. They stressed that molds and mycotoxins cause dry matter and quality loss and are hazardous to the food value chain. They argued that hermetic storage (airtight or sealed storage) effectively creates a modified atmosphere of high $\mathrm{CO}_{2}$ and less $\mathrm{O}_{2}$ concentration, which decreased storage loss, maintained seed viability, and its quality for a long time. In an experiment carried in U.S.A., [34] studied methods of reducing grain storage losses in developing countries and found that seed bags protected stored grain from insect damage for up to nine months provided that the grain was free from insects before storage. Treated bags or netting did not provide control if the grain contained insects, thus it is necessary to fumigate the grain before storing. Good protection was achieved if the grain was placed in a bag treated with insecticides. No insect infection was observed when grain was stored in an airtight, rigid container that insects or rodents cannot penetrate. Modifying the atmosphere by reducing $\mathrm{O}_{2}$ levels or rising $\mathrm{CO}_{2}$ levels also provided good pest control in 
stored grain. Grain deterioration in storage can be minimized or prevented by keeping the grain dry (less than $12.5 \%$ grain moisture), cool (less than $10^{\circ} \mathrm{C}$ ), and free from insects [35]. The study reported that insects feed on endosperm and/or germ, resulting in losses in grain weight, reduction in the nutritional value, and deterioration in end-use quality in addition to the reduction in seed germination rate.

In a study carried in the Check Republic, [36] analyzed changes in wheat flour properties during a six-month storage period. They found that flour moisture, acidity, and the falling number changed with storage, but no explicit influence and the initial flour properties were proved.

A study carried in Poland [37] estimated the scale of losses in baking and confectionery industry (BCI), determined their causes and assessed the risk of their occurrence, and identified retrieve points (RP) and ways of reducing and preventing losses. The study used an Internet survey method on a sample of 48 bakeries. The results showed that the total scale of losses in Polish BCI reached 2.39\% (in 2017) and 2.63\% (in 2018) of the weight of manufactured products. The loss analysis was presented within respective sections of production: raw materials magazine (RMM), production section (PS), final product magazine (FPM), final product transport (FPT). The highest loss level was reported for PS-1.56\% (2017), 1.85\% (2018). Additionally, 12 loss risks and nine main cause categories were identified. Six potential retrieve points (RP) during the baking processes were indicated: making and handling intermediate products and dough; portioning and forming of dough, baking, customized packing, shipping (storage), transport by own fleet. The type of risk, the cause of losses, their consequences, and manners of preventing losses were specified for each RP.

A study carried in Switzerland [38] quantified food losses at the various stages of the food value chain, identified hotspots and analyses the reasons for losses. The results revealed that the average losses of bread and pastries reached 3-7\%, with an average of $5.1 \%$. The results also showed that the losses are variable, depending on bakery size, location, strategy, and variety of products. One city bakery with between 20 and 30 branches estimated its losses in the major branches at $5 \%$, in the smaller branches up to $20 \%$, with average losses of $8 \%$. Thereof, $1.6 \%$ are reused in their own production (e.g., as breadcrumbs) and $0.4 \%$ are donated. The remaining $6 \%$ are fed to livestock. An old, traditional bakery with a narrow range of steady customers has kept its original philosophy not to overproduce. Most unsold products are consumed by the staff or reused. The losses fed to animals were roughly estimated at $1 \%$ of the volume of sales.

Another study carried in urban areas of Turkey [39] determined the major socioeconomic characteristics of households, bread consumption, and amount of bread waste and their reasons in urban areas of Turkey. The results revealed that the average number of daily purchased bread loaves reached 4.65 per household, whereas the average number of loaves consumed was 4.45. Bread consumption was higher in households with low-income level than those with high-income level. The average rate of daily bread waste in the analyzed households reached $9.63 \%$. It was determined that this rate is maximum in the highest group of income and minimum in the lowest group of income.

Food loss and waste also results in extra $\mathrm{CO}_{2}$ emissions, eventually affecting the environment [11]. Using the life cycle approach, a report [40] from the Food and Agriculture Organization of the United Nations (FAO), estimated that globally, about 3.3 giga tons of $\mathrm{CO}_{2}$ equivalent is emitted due to food that was produced but not utilized. Another study [41] estimated the blue water footprints to be $250 \mathrm{~km}^{3}$. Food loss and waste also has implications on land use. On the global scale, in 2007, about 1.4 billion hectares of land was wasted by growing food that was not consumed [42]. For example, a study conducted on rice postharvest losses in Nigeria [43] estimated that the lost paddy accounted for 19\% of the total cultivated area. A study which compared Belgian (BE) and New Zealand (NZ) apples [44] concluded that food waste and losses contributed up to $25 \%$ for $\mathrm{BE}$ and or $15 \%$ for NZ apples, as all lost food travels in vain through the food chain and needs to be disposed of. In their study carried in the UK, [45] found that the carbon footprint of avoidable food waste ranged from 2000 to $3600 \mathrm{~kg} \mathrm{CO}_{2}$-eq per ton. Another study [46] 
conducted in the UK compared different food disposal methods and concluded that for all foods, landfill incurs the highest emissions, even with methane capture while donating food to be eaten by humans is the best option. A study carried in Korea [47] also compared environmental impacts of various food waste management systems and found that dryerincineration was an available alternative for food waste recycling in metropolitan areas.

\section{Materials and Methods}

Food loss was defined by [48] as a measurable reduction in the quantity and quality of food. They arise from the fact that freshly harvested agricultural produce is a living thing that breathes and undergoes changes during post-harvest handling. Loss should not be confused with damage, which is the visible sign of deterioration; for example, chewed grain can only be partial. Damage restricts the use of a product, whereas loss makes its use impossible. In this paper, we follow the lifecycle of food approach suggested by [12] to measure and/or estimate food loss and wastage at each node of the wheat value chain in Egypt. Life cycle assessment (LCA) is a "cradle-to-grave" approach where assessment starts from the extraction of raw material from the ground and ends at a point where final waste or used product is returned to the ground [49]. In this paper, we apply LCA to assess the levels of farm-to-fork losses and wastage of wheat. For the purpose of credibility and to ensure consistency and comparability with other similar studies, we apply the Food Loss and Waste (FLW) Protocol outlined by [19] that are based on the recommendations of the international initiative led by the World Resource Institute (WRI). The FLW Protocol developed a global accounting and reporting standard, known as the FLW Standard, which enables a wide range of entities - countries, companies, and other organizations — to report how much food loss and waste is created credibly, practically, and consistently, and to identify where it occurs.

\subsection{Sample Selection and Procedures}

From the outset, we disclose that our sampling procedures are purely ad-hoc for which we do not claim statistical representation to our samples. While the sampling procedure used is aimed at ensuring fair representation of all types of agro-ecologies, households, farms, restaurants, storage facilities, etc., given the breadth of the coverage of the study (including all nodes from the field to the fork) and the limited financial and human resources that were available for this study, sampling methods involving some level of randomization that would make statistical inference possible with definite levels of confidence and precision were practically impossible. Moreover, because of the ease of getting the permission from farmers to carry the measurements of losses during production, relatively larger sample of crop fields were included while due to difficulty of getting the permission from flour mills, grocery stores, and even households, the samples were much smaller. Therefore, sampling bias is more likely inherent and hence the results of our study should be taken with caution. The main objective here is to provide an estimate using consistent and technically acceptable methods that will serve as a basis for policy interventions as well as to induce further research on the topic.

This study is part of the second phase of a project which started in the $2011 / 2012$ production season. As is the normal practice of the research organizations where all the authors work, oral consent was obtained from all participating farmers, businesses, and government establishments (particularly storage facilities). However, no ethics clearance was obtained as our organizations did not have the culture and institutional review boards at the time of the field work.

Three governorates were purposely selected for pre-harvest, harvest, and post-harvest losses activities of the project in the two wheat-growing seasons of 2016/2017 and 2017/2018. Each governorate was selected to make a good representation of the three major wheatgrowing regions of Egypt as follows: 
Dakahlia governorate represents the Lower Egypt (also called the Delta) region. The Lower Egypt region constitutes two-thirds of the total national wheat area in Egypt. The wheat area in Dakahlia was 92,581 ha in 2017/2018 and ranked third among all governorates in the country, with an average wheat yield of $6.92 \mathrm{ton} / \mathrm{ha}$. Dakahlia is located at the northeast corner of the Egyptian Delta region. In 2018, the total population of the governorate was 6.61 million.

Bani Suef governorate represents the Middle Egypt region located in the central part of the country. In 2017/2018, Bani Suef had a total wheat area of 49,793 ha with an average yield of 6.65 ton/ha. The total population of Beni Suef governorate in 2017/2018 was 3.28 million.

Qena governorate represents the Upper Egypt region at the southern part of the Nile valley characterized by high temperature. The total wheat area in the governorate was 37,832 ha in the $2017 / 2018$ season, with an average yield of 6.50 tons/ha. The total population of the Qena governorate in 2018 was 3.36 million. Detailed distribution of the samples is provided in Table 2.

Table 2. Sampling design.

\begin{tabular}{|c|c|c|c|c|c|}
\hline & $\begin{array}{c}\text { Sample Size per } \\
\text { Governorate }\end{array}$ & $\begin{array}{c}\text { Number of } \\
\text { Governorates }\end{array}$ & Replications & Seasons & Total Samples \\
\hline \multicolumn{6}{|l|}{ Pre-harvest and harvest losses } \\
\hline Pre-harvest & 25 & 3 & 2 & 2 & 300 \\
\hline Mechanical harvest & 25 & 3 & 2 & 2 & 300 \\
\hline Hand harvest & 25 & 3 & 2 & 2 & 300 \\
\hline Threshing and cleaning & 25 & 3 & 2 & 2 & 300 \\
\hline \multicolumn{6}{|l|}{ Storage Losses } \\
\hline Farmer's store & 10 & 3 & 2 & 2 & 120 \\
\hline Government (Shona) & 10 & 3 & 2 & 2 & 120 \\
\hline Government (silos) & 2 & 3 & 2 & 2 & 24 \\
\hline \multicolumn{6}{|l|}{ Transportation Loss } \\
\hline Field to farmer store & 23 & 3 & 1 & 2 & 138 \\
\hline Field to accumulation point & 23 & 3 & 1 & 2 & 138 \\
\hline Accumulation points to mills & 23 & 3 & 1 & 2 & 138 \\
\hline Silos to mills & 23 & 3 & 1 & 2 & 138 \\
\hline \multicolumn{6}{|l|}{ Food processing } \\
\hline Mills & 2 & 3 & 1 & 2 & 12 \\
\hline
\end{tabular}

To the extent possible, a selection from each governorate of farmers, storage facilities, transportation trucks and distance, food processing, marketing, and consumption units for inclusion into the samples of this study was carried out to represent their distribution nationally. The losses per ton at each of the different units obtained by averaging across similar units in the samples are then aggregated to national levels. This is done by taking weighted averages across the different sizes/types of the units within the category using their relative weights in the national composition of the units as weights. For example, suppose that there are three types of storage facilities in the country, namely, A, B, and C. Suppose in our sample, there are 10 units of type A, 5 units of type B, and 12 units of type C. Suppose we carried measurement of losses in all of the 27 units and the average loss in type $\mathrm{A}$ is $3 \%$, and the average losses in types $\mathrm{B}$ and $\mathrm{C}$ are $5 \%$ and $8 \%$, respectively. Suppose also that the share of type $\mathrm{A}$ in total national storage capacity is $40 \%$, and that of types $\mathrm{B}$, and $\mathrm{C}$ are $25 \%$ and $35 \%$, respectively. Then, the national storage loss is calculated as the sum product of the share of each type of storage in total national storage capacity and the average storage loss measured in each storage type. In our example, national storage loss $(\mathrm{NSL})=40 \% \times 3 \%+25 \% \times 5 \%+35 \% \times 8 \%=5.25 \%$. This procedure was used for estimating national-level losses at each node of the wheat value chain. For management, preharvest, and harvest losses, wheat areas under the different management and harvesting 
methods were used. For consumption loss in restaurants, the shares of low-end (fast food), middle class, and high-end restaurants in the total amount of wheat-based food sold in the country were used as weights.

Losses can be measured by weight or volume, while quality loss can only be assessed visually or through laboratory analysis. In this study, estimates of food losses and wastage are generated, whenever possible, through physical measurements. In cases where it is impractical or cultural barriers prohibit physical measurement, alternative methods are used, as discussed below. Losses related to straw yields are ignored in this study. All measurements or estimates of food loss and wastage were made for one year (based on a wheat-growing season spanning from planting until the last day before the start of land preparation for the subsequent cropping year) and with two replications, i.e., two years (2016/2017 and 2017/2018).

\subsection{Estimation of Farm Management-Related Losses during Crop Growth on the Field}

Experimental approaches would be the best methods to carry measurement of losses during the growing period of the crop, and, in their absence, simulation models can be used. However, the study involves several combinations of practices making it practically impossible to carry experiments making the use of suitable models that consider all the agronomic and socioeconomic factors affecting yield in Egypt necessary. However, to our knowledge, there is no such model readily available for us to use. The need for such studies to be carried on farmers' fields further increases the complexity and the challenge. Measurement of losses associated with management in farmers' fields is especially difficult as there is huge variation in management practices among farmers. The difficulty is compounded by the fact that they represent production that would have been possible if the farmers used optimal management practices, including the use of improved varieties, optimal planting and harvesting dates, optimal agronomic practices covering methods, timing and rates of seeding, fertilization, pesticide, and herbicide applications.

This paper followed [17] and used the stochastic frontier production function (SFPF) approach [50] to indirectly estimate the level of production that is lost due to failure to apply optimal management practices (i.e., the level of production that could have potentially been realized if optimal practices were followed). In SFPF, production units (firms, regions, countries, etc.) are assumed to produce according to a common technology and reach the frontier when they produce the maximum possible output for a given set of inputs. The technical efficiency values that are derived from the estimates of the SFPF model can be used to generate an estimate of how much less (often in percentages) each sample firm (in our case wheat field) is producing as compared to the most efficient wheat field(s) on which comparable amounts of inputs are used but the highest yield(s) are obtained. The later field is therefore assumed to represent a $100 \%$ efficiency level among the sample fields.

In this study, the SFPF is estimated using data obtained from a sample survey of 691 wheat fields drawn using a stratified sampling procedure from three governorates in Egypt, namely Dakahlia, Sharkia, and Kafr Sheikh (all from lower Egypt). The survey was carried in 2017 to measure the impacts of a new wheat technology package introduced by a project. While we admit that there could be some efficiency differences across the three regions (lower, middle, and upper Egypt), we assume they are negligible. Hence, the estimates can equally apply to middle and upper Egypt as well.

Mean percentage efficiency level (MPEL) for the typical Egyptian farmer and then the total farm management-related loss (TFMRL), which represents the sum of managementrelated loss (MRL), and harvest loss (HL), were estimated as follows:

$$
\text { TFMRL }=\text { EMEF }- \text { MPEL }
$$

EMEF is the efficiency level of the most efficient farmers producing on the production frontier, which is assumed to be $100 \%$. This assumption is based on the premise that given the circumstances (weather, quantity, and quality of natural resources, available technologies, etc.) governing the farmers in the country, the estimated frontier is the 
maximum level a given farmer can achieve. This production frontier is less than what is obtained in experimental plots. Still, they are more appropriate and realistic for this analysis as they represent what farmers who follow best practices are able to produce is limited by all the challenges as the rest of their peers. Then, the management-related loss is computed as the difference between total production-related loss (TPRL) and the sum of pre-harvest loss (PHL), and harvest loss (HL), both of which, are measured (detailed discussion below).

\subsection{Measurement of Pre-Harvest and Harvest Losses}

For the measurement of PHL and HL, a total of 75 fields owned by 75 farmers (25 from each of the Dakahlia, Bani Suef, and Qena governorates) were systematically selected to represent small, medium, and large fields. Based on the most common methods of harvesting and threshing in the country, measurement of pre-harvest and harvest losses were carried for the following four combinations of harvesting and threshing methods: (1) Manual harvesting and manual threshing; (2) Manual harvesting and mechanical threshing; (3) Reaper harvesting without bundling but with mechanical thresher; and (4) Reaper harvesting with bundling and mechanical threshing. The number of farmers (out of 25) using the different combinations of harvesting and threshing methods differed from one governorate to another depending on the facilities in each site in the two years of the study. For example, reapers with bundling are not as common in Egypt as those without bundling. During our study, only two reapers with bundling were available in Dakahlia and two in the Qena governorate, while this type of reaper was not available in Bani Suef.

In this study, maximum attainable yield under farmers' current management was defined as the grain yield at physiological maturity harvested and threshed without (or with minimum) loss. Likewise, the maximum harvestable yield was defined as the grain yield that can be obtained if there is no or minimum loss during harvesting and threshing during full maturity (defined here as the time during which the farmer does the actual harvesting and threshing).

The maximum grain yield was measured in two seasons by taking two samples of $1 \mathrm{~m}^{2}$ each at physiological maturity from each farm. These samples were carefully harvested manually using sickles. The samples were then dried, carefully threshed, and cleaned manually to avoid grain loss and measured using digital scales. Likewise, to measure the maximum harvestable yield, two samples of $1 \mathrm{~m}^{2}$ each were taken at full maturity from each farm. These samples were carefully harvested, threshed, and cleaned manually to avoid grain loss and measured using digital scales.

Observed yield is defined as the actual grain yield that the farmer obtains using his/her own harvesting, bundling, and threshing methods, whichever is applicable. The harvesting, bundling, and threshing practices used by each sample farmer were recorded. If a farmer uses manual harvesting, the study team randomly picks two $1 \mathrm{~m}^{2}$ area samples from the field and asks the farmer to harvest and thresh them manually or mechanically, just how they would usually do it. Then, the study team weighed the grain yields and recorded them. If the farmer used mechanical harvesting using reapers, then the study team randomly picked a $200 \mathrm{~m}^{2}(10 \mathrm{~m} \times 20 \mathrm{~m})$ area, delineate it, and asked the farmer or the reaper operator to harvest it as they would normally. Then, depending on whether the reaper is with or without bundling, the study team asked the farmers to do what they usually do and thresh it mechanically. Then, the study team measured the grain weight and recorded it. All yield measurements for the different methods were converted into ton/ha.

Finally, the preharvest loss is measured as the difference between the maximum attainable yield and the maximum harvestable yield. This represents what has been lost due to lodging, shattering, and bird and rodent attack between physiological maturity and full maturity. In the same way, harvest loss was measured as the difference between the maximum harvestable yield and observed yield. This represents grain lost during 
harvesting, which includes shattering, dropped heads and grains, and grain that is not separated from the residue and goes out with the straw.

\subsection{Measurement of Storage Losses}

Our study on storage loss included all three forms of wheat grain storage in Egypt: farm storage, government-owned open-air storage (locally called Shona), and governmentowned silos. In this study, we assumed that hermetic bags could provide the maximum achievable protection in Egyptian storage conditions. Hence, losses in hermetic bags will be considered the lowest possible.

Two $50 \mathrm{~kg}$ wheat grain bulk were weighed using a digital scale (Accuris model: W T $42,002 \mathrm{GFE}$ ). Grain moisture content and grain temperature were measured using Gmk303-grain moisture meter S/N 2524 and digital thermometer Type K, model: D.M.—6801 A, respectively. Then one of the $50 \mathrm{~kg}$ wheat grain bulk is placed in the traditional storage material, and the other $50 \mathrm{~kg}$ is placed in a hermetic bag. Except for the storage material, both $50 \mathrm{~kg}$ grain bulks are kept under the traditional management conditions and kept in the same place. These measurements were recorded at the beginning of storage and every month afterward to detect changes in wheat grain moisture and temperature in addition to the test weight to measure grain loss during storage. In addition, a sample of one kilogram of grain was taken after the measurements every four months and sent to a lab for quality analysis. Data were recorded every month for 12 months each of the two study years (May 2017 to April 2018) and May 2018 to April 2019). The loss in each storage type is compared with the loss in the corresponding hermetic bag. Finally, annual storage loss in each storage type is calculated as the difference between the annual loss from the traditional storage type and the corresponding loss in the hermetic bag placed beside the standard storage material under consideration. More details on the procedures followed for measuring loss in each of the different storage types are provided below.

\subsubsection{On-Farm Storage}

Ten farmers from each governorate were randomly selected for the storage loss study. Farmers' packages or bags which they use for storage were used for the study. Farmers usually use either plastic bags, jute bags, or plastic barrels. Two $50 \mathrm{~kg}$ wheat grain bulks were weighed and kept separately from the farmer's largest stored bulk. One of the $50 \mathrm{~kg}$ wheat grain bulk was placed in the same storage material (bag or barrel) used by the farmer. As a benchmark, we placed the other $50 \mathrm{~kg}$ of wheat from the same bulk in a hermetic bag and kept them both in the same room where the farmer had kept his/her stored grain.

\subsubsection{Storage in Shona (Open-Air Storage)}

Shona is open-air storage either sheltered or un-sheltered. Jute bags packed with 80-100 kg of wheat were stacked in the Shona in this storage system. Two Shona from each governorate were selected for the study. In each Shona, as in on-farm storage, two samples of wheat grains $(50 \mathrm{~kg}$ ) were stored in two bags (one in the same jute bags used for Shona storage and another in a hermetic bag).

\subsubsection{Storage in Silos}

One silo in each of Bani Suef and Qena governorates and two silos in Dakahlia were selected for this study. Due to the difficulty of carrying the experiment in the silos in a way comparable with the benchmark (hermetic bag), data collection from the silos was limited to monthly measurement of grain temperature, which was used to estimate grain loss in each silo. 


\subsection{Transportation Losses}

Transportation loss included losses during shipment of grain from ports to government storage facilities (Shona and silos), from the field to farmers' own storage, and from farmers' storage to governmental stores (Shona and silos). It also includes losses during the shipment of grain from farmer's storage to market and from silos and Shona to mills. By its very nature, carrying the measurement of transportation losses is disruptive to the normal operation of transporters and storage facilities. Therefore, in this study, measurement of losses focused only on measuring losses during transportation of wheat grain from big farms to silos, from silos to mills, and from ports to silos (for imported wheat) using big trucks. The procedures used for measuring transportation loss are that trucks were weighed after loading at the origin and upon arrival at the destination; the fuel tank's amount was also recorded at the origin and at the destination (assuming $1 \mathrm{~L}=1 \mathrm{~kg}$ ). In Egypt, the allowable transportation loss (without legal implications to the transporter) is officially fixed by law at $0.30 \%$ for both local and imported wheat.

\subsection{Processing Loss}

One mill in each governorate was selected for the measurement of processing losses. A second set of three mills (one mill per governorate) were selected in the second year to increase the variation, making the total number of mills included in this study six. Processing loss was calculated using the data sheets obtained from each mill for a month. The main variables used for calculation of processing loss are the beginning and ending inventory (ton), amount of wheat that was shipped into the mill during the 30 study days (ton), moisture content before processing, moisture content of processed products, i.e., flour, bran for human consumption, and bran for animal consumption, and weight of the different processed products. Processing loss was calculated as the difference between the sum of the weight of initial inventory and the weight of the total amount of grain shipped into the mill during the study month (all before milling). The sum of ending inventory and the total weight of all the final products after adjusting the weights of all the three types of the processed products by converting them all into the same moisture content as the wheat before processing.

\subsection{Marketing Loss}

For estimating marketing loss, five stores and three bakeries were selected in each governorate. The same number of stores and bakeries but different ones were used in the second year and made the total number of stores and bakeries included in this study 30 and 18, respectively. The selection of stores and bakeries was carried in such a way that neighborhoods' main types and economic levels. The national estimate of marketing loss was made using each type of neighborhood at the national level as weights.

\subsection{Consumption Loss}

Consumption losses occur during consumption (leftover food after being served, cooked food disposed-off without being served because the excessive amount was prepared, or because it got spoiled, or food supplies are disposed-off because of expiration in restaurants, households, universities, and military, construction site, and other camp site cafeterias. Due to cultural barriers and the sensitive nature of the topic, only consumption loss in restaurants is measured. For losses during consumption, expert estimates were elicited.

Five restaurants were selected from each governorate in the two years of the study, restaurants in the first year were different from those in the second year, making the total 30 (10 in each governorate in the two years). The selection of restaurants for inclusion into the sample was carried in such a way that all the major restaurant types, i.e., high-end (5-star restaurants), middle-class restaurants, and lower-end (fast food type restaurants mostly in more impoverished neighborhoods) were represented. 


\section{Results and Discussion}

Our results show that the total farm-to-fork loss in Egypt is 20.62\% of the total wheat supply from both domestic production and imports implying annual loss of 4.4 million tons of wheat. The highest loss $(4.27 \%)$ occurs in the marketing node followed by loss in the storage node $(4.00 \%)$. When looked at each node alone, the highest losses occur at harvest $(9.26 \%)$ and during crop growth on the field $(8.22 \%)$. While the high research investment for increasing productivity is well-aligned with these results, more attention will need to be given to harvest loss reduction.

\subsection{Preharvest Loss}

Based on the manual harvest of a $1 \mathrm{~m} \times 1 \mathrm{~m}\left(1 \mathrm{~m}^{2}\right)$ wheat area at physiological and full maturity, the two-year average pre-harvest loss, which is calculated as the difference between the average maximum attainable yield and average maximum harvestable yield, was found to be only $0.85 \%$ ( $0.8 \%$ in $2016 / 2017$ and 0.9 in 2017/2018). This result is not surprising because, over the years, preharvest loss is known to have reduced substantially, mainly attributed to the successful wheat breeding program in Egypt (the leading in the region), which developed improved varieties that are resistant to shattering and lodging. While the size of pre-harvest losses relative to harvest losses found in this study are comparable to that which was reported by a study carried in Iran [21], our estimate is higher than the $0.52 \%$ estimated in the study. Given its negligible size, the presentation of the detailed results of pre-harvest loss is omitted here.

\subsection{Harvest Loss}

Area-weighted averages of measured maximum harvestable yield and observed yield from the 25 sample fields in each governorate are presented in Table 3. In Lower Egypt, wheat is planted mostly after rice, corn, or other vegetable crops. In Middle and Upper Egypt, wheat is planted after maize, sorghum, and vegetables. Therefore, there is a large variability among farmers' yields.

Table 3. Measured harvest and threshing loss by governorate, major types of harvesting used in the governorate, and year -Governorate level.

\begin{tabular}{|c|c|c|c|c|c|c|c|c|c|c|}
\hline \multirow{3}{*}{$\begin{array}{l}\text { Governorate } \\
\text { (Region) }\end{array}$} & \multirow{3}{*}{ Harvest Type } & \multirow{3}{*}{$\begin{array}{c}\text { Share of This } \\
\text { Harvesting Method } \\
\text { in Total Regional } \\
\text { Wheat Area (\%) }\end{array}$} & \multicolumn{4}{|c|}{$2016 / 2017$} & \multicolumn{4}{|c|}{$2017 / 2018$} \\
\hline & & & \multirow{2}{*}{$\begin{array}{l}\text { Max } \\
\text { Yield } \\
\text { Ton/Ha }\end{array}$} & \multirow{2}{*}{$\begin{array}{l}\text { Observed } \\
\text { Yield } \\
\text { Ton/Ha }\end{array}$} & \multicolumn{2}{|c|}{ Loss } & \multirow{2}{*}{$\begin{array}{l}\text { Max } \\
\text { Yield } \\
\text { Ton/Ha }\end{array}$} & \multirow{2}{*}{$\begin{array}{l}\text { Observed } \\
\text { Yield } \\
\text { Ton/Ha }\end{array}$} & \multicolumn{2}{|l|}{ Loss } \\
\hline & & & & & Ton/Ha & $\%$ & & & Ton/Ha & $\%$ \\
\hline \multirow{3}{*}{$\begin{array}{c}\text { Dakahlia } \\
\text { (Lower Egypt) }\end{array}$} & $\begin{array}{l}\text { Reaper without } \\
\text { bundling }\end{array}$ & $45 \%$ & 7.43 & 6.73 & 0.71 & 9.42 & 7.08 & 6.45 & 0.63 & 8.88 \\
\hline & $\begin{array}{l}\text { Reaper with } \\
\text { bundling }\end{array}$ & $30 \%$ & 8.14 & 7.32 & 0.82 & 10.00 & 7.17 & 6.50 & 0.67 & 9.31 \\
\hline & Rice harvester & $25 \%$ & 8.28 & 7.13 & 1.15 & 13.88 & 6.99 & 6.42 & 0.57 & 8.09 \\
\hline \multirow{2}{*}{$\begin{array}{c}\text { Beni Suef } \\
\text { (Middle Egypt) }\end{array}$} & $\begin{array}{l}\text { Reaper without } \\
\text { bundling }\end{array}$ & $10 \%$ & 7.45 & 6.35 & 1.10 & 14.80 & 8.633 & 8.05 & 0.58 & 7.51 \\
\hline & Manual harvest & $90 \%$ & 6.91 & 6.06 & 0.85 & 12.25 & 8.56 & 7.71 & 0.85 & 3.86 \\
\hline \multirow{2}{*}{$\begin{array}{c}\text { Qena } \\
\text { (Upper Egypt) }\end{array}$} & $\begin{array}{l}\text { Reaper without } \\
\text { bundling }\end{array}$ & $10 \%$ & 10.14 & 8.98 & 1.16 & 11.44 & 7.77 & 7.13 & 0.64 & 8.22 \\
\hline & Manual harvest & $90 \%$ & 8.06 & 7.60 & 0.46 & 5.75 & 7.66 & 7.05 & 0.61 & 7.92 \\
\hline
\end{tabular}

In Dakahlia, maximum harvestable yield in 2016/2017 ranged from 7.43 ton/ha (reapers without bundling) to 8.28 ton/ha (rice harvester), while farmers' (observed) yields ranged from 6.73 to 7.32 ton/ha. Wheat fields harvested by rice harvesters recorded the highest grain loss with an average of 1.15 ton/ha $(13.88 \%)$, followed by 0.82 ton/ha $(10.00 \%)$ for harvesting by reapers with bundling. At 0.71 ton/ha (9.42\%), the least harvest loss occurred in fields harvested using reapers without bundling. In 2017/18, however, the maximum loss of 0.67 ton/ha $(9.31 \%)$ was observed in fields harvested by reaper with bundling, while the least amount lost 6.42 ton/ha $(8.09 \%)$ was observed in fields harvested using rice harvesters. The contrasting results for rice harvesters are attributed to the preci- 
sion of calibration of the combines. Using area weights for the harvest type (3rd column in Table 2), the mean harvest losses in Lower Egypt for the 2016/2017 and 2017/2018 seasons were $10.72 \%$ and $8.81 \%$, respectively. In Bani Suef and Qena governorates, the only harvesting methods were manual $(90 \%)$ and reaper without bundling $(10 \%)$. Using area weights for the harvest types, the mean harvest losses in Middle and Upper Egypt for the $2016 / 2017$ season were $12.51 \%$ and $6.32 \%$, respectively. The corresponding figures for $2017 / 2018$ were $7.13 \%$ and $9.26 \%$, respectively. By applying the total wheat area in each region (3rd column in Table 3) as weights, the mean harvest losses in the whole of Egypt during the 2016/2017 and 2017/2018 seasons were estimated at $10.16 \%$ and $8.35 \%$ giving an average of $9.26 \%$ (Table 4 ). These levels of losses are much higher than even the highest level of loss (6.83\%) recorded by [21] in Iran. The high contrast with the Iranian situation does not come by surprise because, the Iranian fields studied were harvested by combine harvesters as opposed to those included in Egypt which were mostly harvested manually or using reapers and threshed with small mobile threshers involving high level of loss. The relatively smaller harvest losses (excluding threshing losses) in Egypt recorded by [25] along with our results show that most of the losses happen during transportation and threshing which we believe is true because, manual transportation (if harvester is brought to the field) or transportation by open trucks or horse drawn carts of sheaves to where the thresher is located implies high level of falling grains and heads. Substantial losses are also expected during manual feeding and due to issues related to calibration of the fan speed of the mostly old threshers. Assuming that the transportation conditions in Pakistan and Egypt are comparable, we conclude that threshing loss is higher because [31] found that transportation loss alone amounted to only $0.24 \%$.

Table 4. Measured harvest and threshing loss by governorate, major types of harvesting used in the governorate, and year-Region level.

\begin{tabular}{|c|c|c|c|c|c|c|}
\hline \multirow[b]{2}{*}{ Region } & \multicolumn{2}{|c|}{$2016 / 17$} & \multicolumn{2}{|l|}{$2017 / 18$} & \multicolumn{2}{|c|}{ Two-Year Average } \\
\hline & $\begin{array}{c}\text { Area-Weighted } \\
\text { Harvest and } \\
\text { Threshing Loss (\%) }\end{array}$ & $\begin{array}{l}\text { Total Area } \\
\text { (Hectare) }\end{array}$ & $\begin{array}{c}\text { Area-Weighted } \\
\text { Harvest and } \\
\text { Threshing Loss (\%) }\end{array}$ & $\begin{array}{c}\text { Total Area } \\
\text { (Hectare) }\end{array}$ & $\begin{array}{c}\text { Area-Weighted } \\
\text { Harvest and } \\
\text { Threshing Loss (\%) }\end{array}$ & $\begin{array}{l}\text { Total Area } \\
\text { (Hectare) }\end{array}$ \\
\hline Lower Egypt & $10.72 \%$ & $641,800(52 \%)$ & $8.81 \%$ & 637,035 & $9.76 \%$ & 639,417 \\
\hline Middle Egypt & $12.51 \%$ & $233,923(19 \%)$ & $7.43 \%$ & 229,191 & $9.97 \%$ & 231,557 \\
\hline Upper Egypt & $6.32 \%$ & $234,949(19 \%)$ & $7.95 \%$ & 209,198 & $7.13 \%$ & 222,074 \\
\hline New Valley ${ }^{\wedge}$ & $10.16 \%$ & $116,241(9 \%)$ & $8.35 \%$ & 250,448 & $9.26 \%$ & 183,344 \\
\hline Total & $10.16 \%$ & $1,226,913(100 \%)$ & $8.35 \%$ & $1,325,872$ & $9.26 \%$ & $1,276,392$ \\
\hline
\end{tabular}

${ }^{\wedge}$ Note: New Valley, which is the 4th and last region of Egypt was not included in the sampling. However, for the purpose of national level estimation of losses, the weighted average level of losses in the other 3 regions is assumed for New Valley.

\subsection{Farm Management-Related Loss}

Results of the econometric estimation of the stochastic frontier production function (SFPF) are presented in Table 5. Results show that only the quantity of irrigation water has a positive and significant effect on yield, while the amount of labor and seeding rate have negative and significant effects. Both triple super phosphate (TSP) and urea fertilizers and plot area have no significant effects on yield. The results are consistent with theoretical expectations considering the Egyptian conditions because farmlands are generally small (on average $0.5 \mathrm{ha}$ ) and are highly intensified with very high labor levels and fertilizer applications. The insignificant coefficient estimates show that the typical Egyptian wheat farmer is producing wheat by applying input levels above the marginal product-maximizing levels. The only limiting factor in wheat production in Egypt is irrigation water, consistent with the reality on the ground. Given the reduction in water availability due to climate change and population growth and hence water demand from upstream countries, farmers are applying irrigation water below the marginal product maximizing level. 
Table 5. Coefficient estimates of the stochastic frontier production function (SFPF) model.

\begin{tabular}{|c|c|c|c|}
\hline Variable Name & Variable Description & Coef. & Std. Err. \\
\hline \multicolumn{4}{|c|}{ Yield Equation } \\
\hline lnplot_areaha & Plot area in hectares (ha) & $1.19 \times 10^{-3}$ & $6.66 \times 10^{-3}$ \\
\hline lnlbrha & Number of labor days per ha & $-5.38 \times 10^{-3}$ & $2.40 \times 10^{-3 * *}$ \\
\hline lnirrigha & Quantity of irrigation $\left(\mathrm{m}^{3} / \mathrm{ha}\right)$ & $1.88 \times 10^{-1}$ & $4.02 \times 10^{-2 * * *}$ \\
\hline lntspha & Quantity of TSP fertilizer (kg/ha) & $1.49 \times 10^{-5}$ & $7.43 \times 10^{-4}$ \\
\hline lnureaha & Quantity of Urea fertilizer $(\mathrm{kg} / \mathrm{ha})$ & $-1.33 \times 10^{-2}$ & $3.54 \times 10^{-2}$ \\
\hline lnseedha & Quantity of seed $(\mathrm{kg} / \mathrm{ha})$ & $-1.51 \times 10^{-1}$ & $2.71 \times 10^{-2 * * *}$ \\
\hline _cons & Constant term (intercept) & $8.29 \times 10^{0}$ & $9.42 \times 10^{0}$ \\
\hline \multicolumn{4}{|c|}{ The Inefficiency model } \\
\hline Sex_hhh & Sex of the household head $(1=$ male, $0=$ female $)$ & $-2.04 \times 10^{-2}$ & $1.76 \times 10^{-2}$ \\
\hline lnage_hhh & Age of the household head & $3.08 \times 10^{-2}$ & $1.71 \times 10^{-2 *}$ \\
\hline Total_area & Total area cultivated by the household (ha) & $7.63 \times 10^{-4}$ & $7.67 \times 10^{-4}$ \\
\hline rotation & Rotation was practiced on the plot $(1=$ Yes, $0=\mathrm{No})$ & $7.05 \times 10^{-3}$ & $8.67 \times 10^{-3}$ \\
\hline raisedbed & Raised beds built on the plot? $(1=$ Yes, $0=$ No $)$ & $-4.01 \times 10^{-2}$ & $1.21 \times 10^{-2 * * *}$ \\
\hline ImpVar & Improved wheat variety used? $(1=$ Yes, $0=$ No $)$ & $6.14 \times 10^{-3}$ & $1.14 \times 10^{-2}$ \\
\hline sowdate & Recommended sowing date used? $(1=$ Yes, $0=$ No $)$ & $-2.56 \times 10^{-2}$ & $9.76 \times 10^{-3 * * *}$ \\
\hline harvdate & Recommended harvest date practiced? $(1=$ Yes, $0=\mathrm{No})$ & $-2.26 \times 10^{-2}$ & $1.08 \times 10^{-2 * *}$ \\
\hline past_project & Farmer participated in past projects $(1=$ Yes, $0=\mathrm{No})$ & $-7.71 \times 10^{-2}$ & $1.03 \times 10^{-2 * * *}$ \\
\hline deepsoil & Soil on the plot was deep $(1=$ Yes, $0=$ No $)$ & $-9.46 \times 10^{-3}$ & $1.39 \times 10^{-2}$ \\
\hline _cons & & $1.73 \times 10^{-1}$ & $9.42 \times 10^{0}$ \\
\hline /lnsigma2 & & $-4.93 \times 10^{0}$ & $5.37 \times 10^{-2 * * *}$ \\
\hline /ilgtgamma & & $-2.65 \times 10^{0}$ & $1.74 \times 10^{+2}$ \\
\hline sigma2 & & $7.22 \times 10^{-3}$ & $3.88 \times 10^{-4}$ \\
\hline gamma & & $6.61 \times 10^{-2}$ & $1.07 \times 10^{+1}$ \\
\hline sigma_u2 & & $4.77 \times 10^{-4}$ & $7.73 \times 10^{-2}$ \\
\hline sigma_v2 & & $6.74 \times 10^{-3}$ & $7.73 \times 10^{-2}$ \\
\hline
\end{tabular}

Notes: ${ }^{* * *},{ }^{* *}, *$ represent significance at $0.01,0.05$, and 0.1 levels. The minimum, average, and maximum levels of technical efficiency among the 691 farmers were $73.45 \%, 81.67 \%$, and $91.11 \%$, respectively with standard deviation of 0.05 .

In the inefficiency component of the model, the use of raised beds, sowing and harvesting at the recommended dates, and farmers' experience with past projects which disseminated similar wheat technology packages all are highly significant $(p<0.01)$ in reducing technical inefficiency. All these results are consistent with the theoretical expectation because, being instrumental in reducing the quantity of water needed per ha and increasing yield [51], raised beds effectively enhance efficiency in the Egyptian wheat fields. The recommended planting and harvesting dates were also meant to increase yield and efficiency (or reduce inefficiency). Older farmers are found to be inefficient relative to younger farmers, which is expected as younger and more energetic farmers are likely to accomplish more in a given time on the farm than the same amount of time spent by an older farmer.

The technical efficiency level of the most inefficient wheat farmer in Egypt is $73.45 \%$ which shows that the most inefficient farmer is producing only $26.55 \%$ lower than the most efficient farmer applying the same level of inputs and using the same dates of harvesting and the same types of harvesting methods. The maximum efficiency level of the farmers producing below the frontier is $91.11 \%$, with a national average efficiency level of $81.67 \%$. This shows that there is still some room for boosting the productivity of the typical Egyptian farmer. By removing inefficiencies, improving their input mixes, and harvesting methods, the typical Egyptian farmers can increase their yield by $18.33 \%$. In other words, the sum of poor management, preharvest, and harvest losses is $18.33 \%$. Similar studies carried in the MENA region including Syria [52] and Jordan [17] also gave comparable levels (22\% and $19.7 \%$, respectively) of losses on the field. Given that the two-year average preharvest and harvest losses were measured to be $0.85 \%$ and $9.26 \%$, farm management-related losses were indirectly estimated at $8.22 \%$ (i.e., $18.33-0.85-9.26 \%$ ). 


\subsection{Transportation Loss}

Measurement of transportation loss was carried only in the second year (2017/2018) of the project. The weighted average of measured transportation losses in Lower, Middle, and Upper Egypt were $0.2 \%, 0.29 \%, 0.15 \%$, respectively. The weighted national average transportation loss was estimated at $0.21 \%$ which is close to the $0.2 \%$ allowable loss officially used for shipments in the country. This estimate is comparable to the $0.29 \%$ transportation loss [17] found in Jordan.

\subsection{Storage Loss}

Storage loss was fully carried for both 2016/2017 and interrupted for the 2017/2018 season. In Bani Suef, all three types of storage types (farm, shona, and silo), which constitute $50 \%, 20 \%$, and $30 \%$ of total storage were studied, respectively. The measured levels of losses in each storage type were $6.47 \%, 10.36 \%$, and $10.68 \%$, respectively. In Dakahlia and Qena, however, only the farmer and shona storages were studied. The measured levels of farm and shona losses in Dakahliay were $2.05 \%$ and $4.48 \%$, respectively, while the corresponding figures for Qena were $4.6 \%$ and $4.51 \%$, respectively. Therefore, the weighted average storage loss in the country was estimated at $4.58 \%$ (i.e., $4.58 \%$ of the grain that is stored is lost due to grain respiration, mold, insect and rodent damage, and spoilage due to rain, and other factors). These results are over 50\% less than the storage losses reported by [17]. However, in relative terms, storage loss in Egypt ranked second only next to marketing loss which is consistent with other studies [53-55] which found storage loss being the most important source of loss.

\subsection{Processing Loss}

While processing loss can occur at many levels, including milling, baking, and pasta, and during manufacturing of other wheat-based foods, due to lack of access and restrictions related to keeping company secrets, this study was carried only on losses during milling. The total milling loss in 2016/2017 and $2017 / 2018$ were $1.9 \%$ and $1.76 \%$, respectively, leading to an average of $1.83 \%$. This is again much less than the milling loss of $0.45 \%$ found by [17] which can be explained by the size of operation, mill calibrations, and age of mills.

\subsection{Marketing Losses}

Marketing loss can happen during sales and storage of food items. In this study, storage loss measurement focused on the items that are believed to be most important, namely loss during sales by the bakeries and grocery stores. Marketing loss turned out to be among the most important sources of losses in the country. Our estimates show that nationally, the marketing losses in 2016/2017 and 2017/2018 were about $3.63 \%$ and $5.88 \%$, respectively, leading to a two-year average of $4.76 \%$. This is much higher than the $1.63 \%$ marketing loss [17] found in Jordan. Differences in inventory and stock management and lack/presence of proper cooling and storage facilities can explain these differences.

\subsection{Consumption Losses}

\subsubsection{Losses and Wastage during Consumption at Restaurants}

Based on measurements that were carried, total consumption loss and wastage in the country was measured at $11.57 \%$. Restaurant managers reported that about $3.93 \%$ was given away $(1.32 \%$ for human consumption and $2.61 \%$ for human consumption and animal feed while the remaining $7.65 \%$ was dumped in the garbage. For this study, only what has been dumped into the garbage $(7.65 \%)$ is considered food loss and wastage during consumption in restaurants as that which was given away as human food or animal feed is still being used for human consumption directly and indirectly, respectively. 


\subsubsection{Losses and Wastage during Consumption at Households}

Due to cultural and ethical barriers in Egypt, measurement of consumption loss and wastage in households was not carried. Therefore, based on their experience and considering their households, the team members estimated that for a given unit of wheatbased food, losses and wastage during household consumption would be utmost $25 \%$ of the same amount entering the typical restaurant. Accordingly, loss during consumption in households was estimated at $1.91 \%$. This is quite in contrast with the $12.95 \%$ consumption loss at households found by [17] in Jordan. The research team stressed that these levels are much lower than what it was before 2014 as Egypt was known to have one of the highest losses and wastage of bread in MENA because bread quality in the country was poor, which resulted from the misguided subsidy system. The low estimate for consumption loss during this study is attributed to the government's action in 2014, which targeted the neediest households with food vouchers instead of bread subsidies. In the past, subsidies were given to millers in the form of flour subsidies through which flour prices and bread prices were kept low. As a result, millers had every reason to increase the volume of their output even by highly compromising the flour quality as the subsidy was volumetric. The introduction of food vouchers has encouraged low-income families to rationalize their bread consumption and save some money that they can use to buy other food items. By so doing, the new policy is believed to reduce food waste and improve nutritional intake, especially by poorer households.

\subsection{Aggregation of All Losses and Wastage to the National Level}

Table 6 provides estimates of loss and wastage per unit of food entering each node of the wheat value chain as well as estimates of the percentage of loss in the particular node out of total national wheat that could have been potentially available in the absence of loss which was estimated at 21.51 million tons. Estimation of the latter was carried using appropriate weighting. For example, the percentage loss out of wheat-based food that enters the typical restaurant was $7.65 \%$, while the corresponding figure for households was $1.91 \%$. However, out of the total food consumed in the country, an average of $17.5 \%$ is consumed in restaurants, while the remaining $82.5 \%$ is consumed in households. Therefore, given that $10.16 \%$ out of total wheat that was produced and imported (20.55 million tons) is already lost in the preceding nodes, the share of consumption in total potentially available wheat is $2.50 \%$ [i.e., $(17.5 \% \times 7.65 \%+82.5 \% \times 1.91 \%) \times(100 \%-10.16 \%) \times(20,550,818) / 21,506,718.06]$.

Out of total wheat that could have been available in Egypt (from both local production and imports), $20.62 \%$ is lost or wasted each year, out of which at a level of $4.27 \%$ loss, marketing loss ranks first followed by storage and harvest losses which were $4.00 \%$ and $3.93 \%$ respectively. In terms of loss per unit amount of wheat entering in each node, at $9.26 \%$, harvest loss ranks first, followed by farm management-related loss $(8.22 \%)$, and marketing loss $(4.76 \%)$. 
Table 6. Levels of Food Loss and Wastage along the Wheat Value Chain in Egypt.

\begin{tabular}{|c|c|c|c|c|}
\hline Year & $2016 / 2017$ & $2017 / 2018$ & $\begin{array}{l}\text { Two-Year } \\
\text { Average }\end{array}$ & \\
\hline $\begin{array}{c}\text { Total potential production of wheat including what is lost before and } \\
\text { during harvest (tons/year) = TPP }\end{array}$ & $9,821,457.91$ & $9,191,978.21$ & $9,506,718.06$ & \\
\hline $\begin{array}{l}\text { Total actual national production of wheat or total harvest (tons/year) } \\
\qquad=\mathrm{TH}\end{array}$ & $8,753,009.00$ & $8,348,628.00$ & $8,550,818.50$ & \\
\hline Preharvest loss $($ tons $/$ year $)=$ PrHL & $78,571.66$ & $82,727.80$ & $80,807.10$ & \\
\hline Harvest loss $($ tons $/$ year $)=\mathrm{HL}$ & $989,877.24$ & $760,622.41$ & $872,368.06$ & \\
\hline Total imports of wheat (tons / year) $=$ TIW & $12,000,000$ & $12,000,000$ & $12,000,000$ & \\
\hline Total exports of wheat (tons $/$ year) $=$ TEXW & 0 & 0 & 0 & \\
\hline $\begin{array}{l}\text { Total wheat that could potentially have become available in the } \\
\text { country in the absence of loss (tons/year) = TPAW }\end{array}$ & $21,821,457.91$ & $21,191,978.21$ & $21,506,718.06$ & \\
\hline Total wheat available in the country (tons /year) = TAW & $20,753,009$ & $20,348,628$ & $20,550,818.5$ & \\
\hline Share of restaurants in total national wheat consumption $(\%)=$ SRTC & $20 \%$ & $15 \%$ & $18 \%$ & \\
\hline Share of households in total national wheat consumption $(\%)=\mathrm{SHTC}$ & $80.00 \%$ & $85.00 \%$ & $82.50 \%$ & \\
\hline \multirow{2}{*}{ Percentage Loss at Each Node } & \multicolumn{3}{|c|}{ Loss Per Unit Amount Entering the Node (\%) } & \\
\hline & 2017 & 2018 & Average & Rank \\
\hline Farm management-related loss $(\%)=$ TFMRL & $8.22 \%$ & $8.22 \%$ & $8.22 \%$ & 2 \\
\hline Pre-harvest loss $(\%)=$ PrHLR & $0.80 \%$ & $0.90 \%$ & $0.85 \%$ & 7 \\
\hline Harvest loss $(\%)=$ HLR & $10.16 \%$ & $8.35 \%$ & $9.26 \%$ & 1 \\
\hline Transportation loss $(\%)=$ TLR & $0.27 \%$ & $0.25 \%$ & $0.26 \%$ & 8 \\
\hline Storage loss $(\%)=$ SLR & $4.80 \%$ & $3.60 \%$ & $4.20 \%$ & 4 \\
\hline Processing loss $(\%)=$ PLR & $1.90 \%$ & $1.76 \%$ & $1.83 \%$ & 6 \\
\hline Marketing loss $(\%)=$ MLR & $3.63 \%$ & $5.88 \%$ & $4.76 \%$ & 3 \\
\hline Total consumption loss $(\%)=$ TCLR & $3.06 \%$ & $2.77 \%$ & $2.91 \%$ & 5 \\
\hline $\begin{array}{l}\text { Loss during consumption at restaurants }(\%)=\text { RCLR (Based on actual } \\
\text { measurements) }\end{array}$ & $7.65 \%$ & $7.65 \%$ & $7.65 \%$ & \\
\hline $\begin{array}{l}\text { Loss during consumption at households (\%) = HCLR (assuming 25\% } \\
\text { of loss in restaurants) }\end{array}$ & $1.91 \%$ & $1.91 \%$ & $1.91 \%$ & \\
\hline \multirow[t]{2}{*}{$\begin{array}{l}\text { Share of each node in total loss out of the amount of what entering } \\
\text { the system }(\%)\end{array}$} & \multicolumn{4}{|c|}{$\begin{array}{c}\text { Loss as percentage of total wheat that enters the system } \\
\text { (from local production or imports after discounting the } \\
\text { cumulative amount that has already been lost in the } \\
\text { preceding nodes }(\%)\end{array}$} \\
\hline & 2017 & 2018 & Average & Rank \\
\hline Farm management-related loss $(\%)=$ TFMRL & $3.70 \%$ & $3.57 \%$ & $3.63 \%$ & 4 \\
\hline Pre-harvest loss $(\%)=$ PrHLR & $0.35 \%$ & $0.38 \%$ & $0.36 \%$ & 7 \\
\hline Harvest loss $(\%)=$ HLR & $4.39 \%$ & $3.48 \%$ & $3.93 \%$ & 3 \\
\hline Transportation loss $(\%)=$ TLR & $0.26 \%$ & $0.24 \%$ & $0.25 \%$ & 8 \\
\hline Storage loss $(\%)=$ SLR & $4.55 \%$ & $3.45 \%$ & $4.00 \%$ & 2 \\
\hline Processing loss $(\%)=$ PLR & $1.72 \%$ & $1.63 \%$ & $1.67 \%$ & 6 \\
\hline Marketing loss $(\%)=$ MLR & $3.23 \%$ & $5.35 \%$ & $4.27 \%$ & 1 \\
\hline \multirow{2}{*}{$\begin{aligned} & \text { Total consumption loss }(\%)=\text { TCLR } \\
& \text { Loss during consumption at restaurants }(\%)=\text { RCLR (Based on actual } \\
& \text { measurements) }\end{aligned}$} & $2.62 \%$ & $2.38 \%$ & $2.50 \%$ & 5 \\
\hline & $0.52 \%$ & $0.36 \%$ & $0.44 \%$ & \\
\hline $\begin{array}{l}\text { Loss during consumption at households ( } \%)=\text { HCLR (assuming } 25 \% \\
\text { of loss in restaurants) }\end{array}$ & $2.10 \%$ & $2.02 \%$ & $2.06 \%$ & \\
\hline $\begin{array}{l}\text { Total loss out of the total wheat that would have become potentially } \\
\text { available in the absence of loss }(\%)\end{array}$ & $20.82 \%$ & $20.46 \%$ & $20.62 \%$ & \\
\hline Total amount of wheat that has been lost (tons) & $4,542,281$ & $4,335,916$ & $4,435,696$ & \\
\hline
\end{tabular}

\subsection{Implications on Food and Energy Security, Resources, and the Environment}

Losing or wasting food while it can easily be avoided is not only morally wrong but also has implications on food and energy security, natural resources, and the environment. Losses and wastage of food in the different nodes of the wheat value chain imply unnecessary exploitation of natural resources. For example, the current $20.62 \%$ level of food loss and wastage means the wastage of 4.79 billion $\mathrm{m}^{3}$ of water and 74.72 million GJ of energy 
(equivalent to 2.33 billion liters of diesel). Moreover, assuming average wheat consumption in 2018 of $208.81 \mathrm{~kg} /$ capita, had all wheat-based food losses and wastages been prevented, it would have been possible to feed 21.24 million more people or reduced the country's dependency on imports by $37 \%$, thereby saving the country about 1.1 billion USD from imports, thereby reducing the country's foreign exchange burden.

Assuming a modest $20 \%$ for the total wheat-based food waste to end up in landfills in Egypt (while the remaining $80 \%$ is reused for human consumption or animal feed), a total of 130 thousand tons of wheat-based food is estimated to go to landfills. Using a food waste to carbon dioxide equivalent conversion rate of $2.54 \mathrm{~kg}$, [41] and a food waste to methane emission conversion rate of $0.08 \mathrm{~kg}$ per $\mathrm{kg}$ of food waste [56], this level of food that is dumped in landfills is associated with 260.84 million $\mathrm{kg}$ of carbon dioxide equivalent $\left(\mathrm{CO}_{2}-\mathrm{e}\right)$ and 8.5 million $\mathrm{kg}$ of methane emissions into the atmosphere.

\section{Conclusions and Recommendations}

The amount of food loss and wastage in Egypt is estimated at 20.62\%, associated with the loss of 4.79 billion $\mathrm{m}^{3}$ of water and 74.72 million G.J. of energy. If Egypt managed to eliminate the loss and wastage of wheat-based food, it would have been able to reduce imports by $37 \%$, from which it would save about 1.1 billion USD every year.

While the total loss of $20.62 \%$ can be considered high, it is distributed across the different nodes, each with a relatively small loss level. This makes tackling the issue of food loss and wastage a bit more complicated and expensive. At an average level of only $2.5 \%$, loss during consumption in restaurants and households is relatively low. This is attributed to the most recent policy change where the previously misguided subsidy system has been redirected from flour millers towards consumers. Currently, poor Egyptians are provided with vouchers that they can use to purchase any food item. By so doing, the government has succeeded in reducing food loss, and it is expected that dietary diversity and the nutritional intakes of the poor have improved. Now, efforts for reducing food loss and wastage in Egypt should target the top-ranking sources of wastage, namely, marketing loss $(4.27 \%)$, storage loss $(4.00 \%)$, and harvest loss (3.93\%). Losses in the other nodes are relatively low to warrant much investment.

The practical implications of this study include: (1) Providing training on supply and inventory management systems and creating an incentive system that encourages grocery stores and bakeries to sell food that is approaching its expiry date at a substantially discounted price and creating better disposal mechanisms that do not lead to loss and wastage might help the country to reduce food loss and wastage. (2) Replacing all the open-air grain storage facilities where the substantial loss occurs with improved storage facilities such as silos with proper ventilation and pest control methods can go a long way in reducing storage losses in Egypt. (3) Educating farmers to use reapers with bundling and well-calibrated threshers would also help in reducing harvest and threshing losses. The theoretical implications of this study are that reduction of food loss is not only a matter of food security but also of natural resource conservation and environmental protection. Moreover, strategies that aimed at ensuring food security often focused on increasing productivity, but our results show that reducing food loss and wastage may be more effective because it can enhance productivity growth as well as making effective use of whatever is produced, especially in the drylands which face serious resource constraints.

Estimation of food losses and wastage along the entire wheat value chain required the mobilization of large financial and human resources. However, we acknowledge the limitation of this study pertaining to the small sample sizes at each node which we cannot claim to be representative. Future research can improve on this by covering only one or two nodes at a time using statistically defensible sample sizes as well as in analyzing mechanisms for reducing losses in the nodes such as marketing and storage where losses are the highest.

The findings of this study (the first of its kind in Egypt), we believe, will be useful to raise awareness among the general public and policy makers about the scale of loss and 
wastage and their impacts on food security, natural resource, energy, and the environment. We also believe that it will help the government of Egypt to set priorities for interventions and identify areas of research in the overall effort to reduce losses and wastage in the country. It is also expected to be helpful for donors, development practitioners, and extension personnel.

Author Contributions: Conceptualization, Y.A.Y., A.-A.N., S.R.S.S. and H.H.; methodology, Y.A.Y., A.-A.N., M.A.M.; software, Y.A.Y.; validation, Y.A.Y., M.A.M., A.-A.N., H.H.; formal analysis, Y.A.Y., M.A.M., M.M.M., S.E.I., W.M.G.; investigation, Y.A.Y., M.A.M., M.M.M., S.E.I., W.M.G.; resources, Y.A.Y., M.A.M., S.R.S.S., H.H.; data curation, Y.A.Y., M.A.M., M.M.M., S.E.I., W.M.G.; writingoriginal draft preparation, M.A.M., Y.A.Y.; writing—review and editing, Y.A.Y., M.A.M., M.M.M., S.E.I., W.M.G., A.-A.N., S.R.S.S., H.H.; visualization, Y.A.Y., E.A.; supervision, M.A.M., S.R.S.S.; project administration, S.R.S.S., H.H.; funding acquisition, Y.A.Y., M.A.M., S.R.S.S., H.H. All authors have read and agreed to the published version of the manuscript.

Funding: This research was funded by the Arab Fund for Economic and Social Development (AFESD—agreement No. 200021), the Kuwait Fund for Arab Economic Development (KFAEDagreement No. 200001), the Bill \& Melinda Gates Foundation (BMGF-agreement No. 200052), the OPEC Fund for International Development (OFID—200070), the Islamic Development Bank (IsDBagreement No. 100129), and CGIAR program on wheat (CRP-Wheat-agreement No. 200181).

Informed Consent Statement: Informed consent was obtained from all subjects involved in the study.

Conflicts of Interest: The authors declare no conflict of interest.

\section{References}

1. Sadler, M.; Magnan, N. Grain import dependency in the MENA region: Risk management options. Food Secur. 2011, 3, S77-S89. [CrossRef]

2. Woertz, E. Agriculture and development in the wake of the Arab spring. In Combining Economic and Political Development: The Experience of MENA; International Development Policy Series 7; Luciani, G., Ed.; Graduate Institute Publications: Geneva, Switzerland, 2017; pp. 144-169.

3. Bucchignani, E.; Mercogliano, P.; Panitz, H.J.; Montesarchio, M. Climate change projections for the Middle East-North Africa domain with COSMO-CLM at different spatial resolutions. Adv. Clim. Change Res. 2018, 9, 66-80. [CrossRef]

4. OECD; FAO. The Middle East and North Africa: Prospects and challenges. In OECD-FAO Agricultural Outlook 2018-2027; OECD Publishing: Paris, France; Food and Agriculture Organization of the United Nations: Rome, Italy, 2018. [CrossRef]

5. United States Department of Agriculture (USDA). Grain and Feed Annual Egyptian Wheat Imports Hold Steady Despite Increased Local Production; Foreign Agricultural Services; Report Number: EG2020-0005; United States Department of Agriculture (USDA): Washington, DC, USA, 2020.

6. FAO. The Future of Food and Agriculture-Trends and Challenges. Rome. 2017. Available online: http://www.fao.org/3/i658 3e/i6583e.pdf (accessed on 21 June 2021).

7. HLEF. How to Feed the World in 2050. High Level Expert Forum 12-13 October 2019. Office of the Director, Agricultural Development Economics Division Economic and Social Development Department Viale delle Terme di Caracalla, 00153 Rome, Italy. 2019. Available online: http://www.fao.org/fileadmin/templates/wsfs/docs/Issues_papers/HLEF2050_Global_Agriculture.pdf (accessed on 20 June 2021).

8. Ray, D.K.; Mueller, N.D.; West, P.C.; Foley, J.A. Yield trends are insufficient to double global crop production by 2050. PLoS ONE 2014, 8, e66428. [CrossRef]

9. Gustavsson, J.; Cederberg, C.; Sonneson, U.; van Otterdijk, R.; Meybeck, A. Global Food Losses and Food Waste: Extent Causes and Prevention; Food and Agriculture Organization of The United Nations (FAO): Rome, Italy, 2011; pp. 1-37. Available online: http:/ / www.fao.org/3/a-14068e.pdf (accessed on 20 February 2020).

10. Mesterházy, Á.; Oláh, J.; Popp, J. Losses in the grain supply Chain: Causes and solutions. Stainability 2020, 12, 2342. [CrossRef]

11. Kumar, D.; Kalita, P. Reducing postharvest losses during storage of grain crops to strengthen food security in developing countries. Foods 2017, 6, 8. [CrossRef]

12. Bellemare, M.F.; Çakir, M.; Peterson, H.H.; Novak, L.; Rudi, J. On the measurement of food waste. Am. J. Agric. Econ. 2017, 99, 1148-1158. [CrossRef]

13. Ministry of Agriculture \& Land Reclamation (MALR). Bulletins of Food Ballance Sheet (2000-2019); Ministry of Agriculture \& Land Reclamation (MALR): Cairo, Egypt, 2021.

14. Ibrahim, N.A.; Abdel-Haleem, A.M.H. The role of ARC \& MALR in Addressing Food Loss \& Waste (FLW) in Egypt. Presentation Made at the Joint IFPRI-FAO Seminar "Food Waste and Loss in Egypt" Held on 25 October 2017 in Cairo, Egypt. 2017. Available online: https:/ / www.slideshare.net/ifpri/amal-mhassan-2017-ifpri-egypt-seminar-series-food-loss-and-waste-inegypt/1 (accessed on 21 August 2021). 
15. FAO-Food and Agriculture Organization of the United Nations-Representation in Egypt. Food Loss and Waste in Egypt. Cairo, Egypt. 2019. Available online: http:/ / www.fao.org/3/ca4310en/CA4310EN.pdf (accessed on 21 August 2021).

16. Obeidat, Z.; Obeidat, M.; Obeidat, A. Wasteful consumption of bread: Its levels, sources, and possible solutions: A case study of Jordan. Eur. J. Manag. Bus. Econ. 2015, 7, 163-168.

17. Khader, B.; Yigezu, Y.A.; Duwayri, M.; Niane, A.; Shideed, K. Where in the value chain are we losing the most food? The case of wheat in Jordan. Food Secur. 2019, 11, 1009-1027. [CrossRef]

18. International Center for Agricultural Research in the Dry Areas (ICARDA). Diagnosis of the Current Situation of Pre-and Post-Harvest Losses in the Cereals Sector in Morocco; Final Report of the Project Enhancing Food Security in Arab Countries; International Center for Agricultural Research in the Dry Areas (ICARDA): Beirut, Lebanon, 2020.

19. Hanson, C.; Dias, D.; Fonseca, J.; Timmermans, T.; Lomax, J.; Dawe, A.; Berger, V.; Redd, L.B.; Robertson, K.; Gavilan, I.; et al. Food Loss and Waste Accounting and Reporting Standard; World Resource Institute: Washington DC, USA, 2016. Available online: https:/ / www.wbcsd.org/Programs/Food-and-Nature/Food-Land-Use/Scaling-Positive-Agriculture/Resources/FoodLoss-and-Waste-Accounting-and-Reporting-Standard (accessed on 6 July 2021).

20. Arab Organization for Agricultural Development (AOAD). Arab Food Security Situation Report 2013; Arab Organization for Agricultural Development (AOAD): Khartoum, Sudan, 2013. Available online: http://www.aoad.org/Arab\%20food\%20 security\%20report\%202013.asp (accessed on 7 June 2021).

21. Mirasi, A.; Asoodar, M.A.; Samadi, M.; Kamran, E. The evaluation of wheat losses harvesting in two conventional combines. Int. J. Adv. Biol. 2014, 2, 1417-1425.

22. Ince, A.; Say, S.M.; Kara, O.; Bilgili, E. Comparing of different harvesting systems in wheat harvesting. J. Agric. Eng. 2011, 7, 89-93.

23. Sisman, C.B.; Ergin, A.S. The effects of different storage buildings on wheat quality. Res. J. Appl. Sci. 2011, 11, 2613-2619. [CrossRef]

24. Capone, R.; El-Bilali, H.L.; Debs, P.; Bottalico, F.; Cardone, G.; Berjan, S.; Elmenofi, G.A.G.; Abouabdillah, A.; Charbel, L.; Arous, S.A.; et al. Bread and bakery products waste in selected Mediterranean Arab countries. AJFN 2016, 4, 40-50. [CrossRef]

25. Sattar, M.; Din, M.; Ali, M.; Ali, L.; Waqar, M.Q.; Ali, M.A.; Khalid, L. Grain losses of wheat as affected by different harvesting and threshing techniques. IJRAF 2015, 2, 20-26.

26. Raza, S.; Khalil, A.; Naseem, K.; Gilani, M.A.; Amjad, M.; Masud, T.; Saqlannaqvi, S.M. Effect of house storage receptacles on physico chemical characteristics of wheat, Sarhad. J. Agric. 2010, 26, 275-287.

27. Schrock, M.D. Harvesting Wheat; Department of Biological and Agricultural Engineering, Cooperative Extension Service: Manhattan, NY, USA, 1995.

28. Iqbal, Z.; Pasha, I.; Abrar, M.; Masih, S.; Hanif, M.S. Physico-chemical, functional and rheological properties of wheat varieties. J. Agric. Res. 2015, 53, 253-267.

29. Zafarullah, M. Feasibility Report of Kubota Power Reaper AR-120; Test Report FMI/TSQ2/85; Agricultural Farm Machinery Institute: Quetta, Pakistan, 1985.

30. Sukhbir, S.; Vatsa, D.K.; Verma, M.K. Feasibility and performance evaluation of power tiller operated reaper in hills of Himachal Pradesh. Agric. Eng. 2007, 31, 6-10.

31. Bukhari, S.J.; Baloch, J.M.; Rattar, F.M. Losses in wheat harvesting and threshing. AMA Agric. Mech. Asia Af. $1983,14,61-67$.

32. Singh, G.; Clough, D.G.; Chaudhry, A.P. Performance evaluation of mechanical reapers in Pakistan. AMA Agric. Mech. Asia Af. 1988, 19, 47-52.

33. Kent, N.L.; Evers, A.D. Kent's Technology of Cereals, 4th ed.; Elsevier: Oxford, UK, 1994.

34. Dowell, F.E.; Dowell, C.N. Reducing grain storage losses in developing countries. QAS 2017, 9, 93-100. [CrossRef]

35. Payne, T.S. Harvest and Storage Management of Wheat; Food and Agricutlure Organization of the United Nations: Rome, Italy, 2018. Available online: http:/ / www.fao.org/docrep/006/y4011e0u.htm (accessed on 19 June 2021).

36. Hruskova, M.; Machova, D. Changes of wheat flour properties during short term storage. Czech J. Food Sci. 2002, 20, 125-130. [CrossRef]

37. Goryńska-Goldmann, E.; Gazdecki, M.; Rejman, K.; Kobus-Cisowska, J.; Łaba, S.; Łaba, R. How to prevent bread losses in the baking and confectionery industry? Measurement, causes, management and prevention. Agriculture 2020, 11, 19. [CrossRef]

38. Beretta, C.; Stoessel, F.; Baier, U.; Hellweg, S. Quantifying food losses and the potential for reduction in Switzerland. J. Waste Manag. 2013, 33, 764-773. [CrossRef]

39. Gül, A.; Isik, H.; Bal, T.; Ozer, S. Bread consumption and waste of households in urban area of Adana Province. EJPAU 2003, 6, 10. Available online: http:/ / www.ejpau.media.pl/volume6/issue2/food/art-10.html (accessed on 12 August 2021).

40. Food and Agriculture Organization of the United Nations (FAO). Food Wastage Footprint_Impacts on Natural Resources; Food and Agriculture Organization of the United Nations (FAO): Rome, Italy, 2013.

41. Fox, T. Global Food: Waste Not, Want Not; Institution of Mechanical Engineers: London, UK, 2013.

42. Food and Agriculture Organization of the United Nations (FAO). Toolkit: Reducing the Food Wastage Footprint; Food and Agriculture Organization of the United Nations (FAO): Rome, Italy, 2013.

43. Oguntade, A.E.; Thylmann, D.; Deimling, S.; Giencke, S.; Pickardt, T.; Michler, L. (Eds.) Post-Harvest Losses of Rice in Nigeria and Their Ecological Footprint; Deutsche Gesellschaft für Internationale Zusammenarbeit (GIZ) GmbH: Bonn/Eschborn, Germany, 
2014. Available online: https://wocatpedia.net/images/c/c3/Post-Harvest_Losses_of_Rice_in_Nigeria_and_their_Ecological_ Footprint_online_Version.pdf (accessed on 22 August 2021).

44. Goossens, Y.; Barrens, P.; Custers, K.; van Hemerlyck, S.; Kellens, K.; Geeraerd, A. How origin, packaging, and seasonality determine the environmental impact of apples, magnified by food waste and losses. Int. J. Life Cycle Assess. 2019, 24, 667-687. [CrossRef]

45. Tonini, D.; Albizzati, P.F.; Astrup, T.F. Environmental impacts of food waste: Learnings and challenges from a case study on UK. Waste Manag. 2018, 76, 744-766. [CrossRef]

46. Moult, J.A.; Allan, S.R.; Hewitt, C.N.; Berners-Lee, M. Greenhouse gas emissions of food waste disposal options for UK retailers. Food Policy 2018, 77, 50-58. [CrossRef]

47. Kim, M.H.; Song, H.B.; Song, Y.; Jeong, I.T.; Kim, J.W. Evaluation of food waste disposal options in terms of global warming and energy recovery: Korea. Int. J. Energy Environ. Eng. 2013, 4, 1-12. [CrossRef]

48. Tyler, P.S.; Gilman, G.A. L'évaluation des pertes post-récolte. In Proceedings of the Séminaire de Bamako, Bamako, Mali, 16-28 April 1979; pp. 137-151.

49. Satpute, M.S.; Lamdande, A.G.; Kadam, V.D.; Garud, S.R. Life cycle assessment of food. Int. J. Agric. Eng. 2013, 6, 558-563.

50. Battesse, G.E.; Coelli, T.J. A model for technical inefficiency effects in a stochastic frontier production function for panel data. Empir. Econ. 1995, 20, 325-332. [CrossRef]

51. Yigezu, Y.A.; Abbas, E.; Swelam, A.; Sabry, S.R.S.; Moustafa, M.A.; Halila, H. Socioeconomic, biophysical, and environmental impacts of raised beds in irrigated wheat: A case study from Egypt. Agric. Water Manag. 2021, 249, 106802. [CrossRef]

52. Yigezu, Y.A.; Abdulwahab, M.A.; Shideed, K.; Al-Shatter, T. Implications of a shift in irrigation technology on resource use efficiency: A Syrian case. Agric. Syst. 2013, 118, 4-22. [CrossRef]

53. Bala, B.K.; Haque, M.A.; Hossain, M.A.; Majumdar, S. Post-Harvest Loss and Technical Efficiency of Rice, Wheat and Maize Production System: Assessment and Measures for Strengthening Food Security; Bangladesh Agricultural University: Mymensingh, Bangladesh, 2010. Available online: http:/ / fpmu.gov.bd/agridrupal/sites/default/files/CF-6_of_08_B_K_Bala.pdf (accessed on 20 August 2021).

54. Majumder, S.; Bala, B.; Arshad, F.M.; Haque, M.; Hossain, M. Food security through increasing technical efficiency and reducing postharvest losses of rice production systems in Bangladesh. Food Secur. 2016, 8, 361-374. [CrossRef]

55. Aulakh, J.; Regmi, A.; Fulton, J.R.; Alexander, C. Estimating post-harvest food losses: Developing a consistent global estimation framework. In Proceedings of the Agricultural \& Applied Economics Association's 2013 AAEA \& CAES Joint Annual Meeting, Washington, DC, USA, 4-6 August 2013.

56. Extra Food (EF). Food Waste and the Climate Crisis; Extra Food (EF): Kentfield, CA, USA, 2021. Available online: https://extrafood. org/the-need/food-waste/\# (accessed on 22 June 2021). 